\title{
Health Risk Assessment of Residents in a Tourist City: A Case Study of Nakhon Si Thammarat Province
}

\author{
Jenjira KAEWRAT ${ }^{1,2}$ and Rungruang JANTA ${ }^{1,2, *}$ \\ ${ }^{1}$ School of Languages and General Education, Walailak University, Nakhon Si Thammarat 80160, Thailand \\ ${ }^{2}$ Center of Excellence in Sustainable Disaster Management, Walailak University, \\ Nakhon Si Thammarat 80160, Thailand
}

(“Corresponding author's e-mail: rungruang.ja@mail.wu.ac.th)

Received: 31 July 2020, Revised: 6 December 2020, Accepted: 31 December 2020

\begin{abstract}
Nakhon Si Thammarat is one of the most popular tourist destinations among the secondary tourism cities according to economic promotions. The rapid growth of the tourism industry is evidenced by increasing road traffic, especially at weekends, contributing to high nitrogen dioxide $\left(\mathrm{NO}_{2}\right)$ concentration. The concentration of $\mathrm{NO}_{2}$ was measured in the main tourist destinations of Nakhon Si Thammarat Province. Likewise, health risks from $\mathrm{NO}_{2}$ exposure were also evaluated for the local residents. Air mass movement was applied to indicate risk areas of non-cancer health effects from exposure to $\mathrm{NO}_{2}$. Air samples were collected over 24 hours using a passive sampling technique at 3 areas in the tourist destination on weekdays and weekends during the wet season in 2018 and 2019. Results showed that $\mathrm{NO}_{2}$ concentrations at weekends were 2 - 3 times higher than on weekdays due to increased vehicular traffic. Anthropogenic activities had a greater influence than meteorological conditions on pollutant concentration. The $\mathrm{NO}_{2}$ concentration was within the ambient air quality standard, but toxicological risk quotients for the residents were above the recommended limits for human health. Findings indicated that local residents risked non-cancer health effects from long-term exposure to $\mathrm{NO}_{2}$. Therefore, sensitive residents should avoid outdoor activities on weekends. Moreover, the tourism authority should consider controlling visitor numbers, providing a parking area, and providing public transportation systems to reduce traffic-related pollutants for sustainable tourism in Thailand.
\end{abstract}

Keywords: Tourism, Traffic-related pollutant, Health risk assessment, Nakhon Si Thammarat

\section{Introduction}

Nitrogen dioxide $\left(\mathrm{NO}_{2}\right)$ is recognized as a major traffic-related air pollutant produced by the reaction of nitrogen and oxygen gases during vehicle engines' internal combustion process. Nitrogen is released during fuel combustion at high temperatures and combines with oxygen atoms to form nitric oxide (NO), which then reacts rapidly with oxygen atoms to create $\mathrm{NO}_{2}$. The concentration of $\mathrm{NO}_{2}$ is directly related to traffic volume and flow [1-4]. Beckerman et al. [5] highlighted the correlation between $\mathrm{NO}_{2}$ and many traffic-related pollutants, including volatile organic compounds (VOCs), black carbon, particulate matter (PM), and ozone along major expressways. Exposure to $\mathrm{NO}_{2}$ is associated with adverse health effects, including eye and adnexa diseases, age-related macular degeneration (ARMD), DNA methylation irregularity, respiratory inflammation, asthma, and lung function impairment [6-9]. Duan et al. [10] reported an increase of $0.06-3.51 \%$ in China's cardiovascular deaths for every $10 \mu \mathrm{g} \mathrm{m}^{-3}$ $\mathrm{NO}_{2}$ level increase. Moreover, $\mathrm{NO}_{2}$ is a precursor of traffic-related pollutants such as ozone $\left(\mathrm{O}_{3}\right)$ and $\mathrm{PM}_{2.5}$, presenting indirect health effects from $\mathrm{NO}_{2}$. Additionally, $\mathrm{NO}_{2}$ emitted into the atmosphere reacts with water (humidity) to form nitric acid $\left(\mathrm{NO}_{2}\right)$ and falls as precipitation, known as acid rain, which degrades ecosystems of plants, soil, trees, and buildings. 
http://wjst.wu.ac.th

Tourism is a significant contributor to the economy of Thailand. The Thailand Ministry of Tourism and Sports reported revenue of 300 billion baht from the tourism industry in 2019, with amounts of 100 and 200 billion baht from domestic and international tourism, respectively [11]. Tourism is one of the fastest-growing industries in Thailand because it has both an ancient cultural heritage and natural attractions that draw huge numbers of tourists every year. The Tourism Authority of Thailand (TAT) has also promoted secondary tourism cities since 2018 to alleviate congestion at prime tourist areas and geographically balance economic growth. Nakhon Si Thammarat Province is one of the most popular areas among the smaller cities with various tourist destinations such as mountains, beaches, and cultural heritage. The economy has grown rapidly, and the province received around 350,000 visitors with an income of 1.2 billion baht in 2018 [11]. However, tourism is also a significant contributor to environmental deterioration through waste generation and especially traffic pollution in the form of $\mathrm{NO}_{2}$. Saenz-de-Miera and Rosselló [12] observed the relationship between tourist numbers and lower traffic speed as a result of higher traffic volume and increased congestion. An increase in tourist numbers was positively associated with traffic-related pollutants. Saenz-de-Miera and Rosselló [13] observed a $1 \%$ tourist increase in Mallorca related to a $0.45 \%$ increase in $\mathrm{PM}_{10}$ concentration. Nitrogen dioxide concentration in Chiang Mai and Nakhon Si Thammarat's tourist cities were comparable in the range 13 to $96 \mu \mathrm{g} \mathrm{m}^{-3}$, while the concentration in Seoul, Korea ranged $41-181 \mu \mathrm{g} \mathrm{m}^{-3}$ [14-16]. Results indicated that $\mathrm{NO}_{2}$ levels in tourist cities were influenced by factors such as tourism and other anthropogenic activities. Many studies have investigated air pollutants in tourist cities, but these mainly focused on megacities, and studies of air pollution in natural tourist destinations are limited. Hence, this study explored the effect of tourism on air quality at a natural tourist destination, and it also assessed local residents' health risks. An air mass movement model was used to indicate the risk area from $\mathrm{NO}_{2}$ exposure. Results provide useful basic information for tourism authorities to improve strategy formulation for sustainable tourism in Thailand.

\section{Materials and methods}

\section{Study area}

The study area was located in Kiriwong Village, Lansaka District, Nakhon Si Thammarat Province. This province is located on the Malay Peninsula, which experiences both the Southwest Monsoon and Northeast Monsoon. The rainy season runs from June to February ( 9 months), with only 3 months as the dry season (March to May). Annual temperature and rainfall average $27{ }^{\circ} \mathrm{C}$ and $2,500 \mathrm{~mm}$, respectively. Kiriwong Village is $20 \mathrm{~km}$ from the city of Nakhon Si Thammarat, and this area is known to have the best air quality in Thailand. The village is located in a valley surrounded by mountain ranges, with a river flowing through the middle. Kiriwong Village is a famous natural attraction in the area as a model community for eco-tourism management.

Nitrogen dioxide samples were collected from 3 areas in Kiriwong Village. The $1^{\text {st }}$ sampling site was located at Kiriwong Bridge, known as the gate of the village. This area is a famous place where visitors take photographs. The $2^{\text {nd }}$ sampling site was on the road in the village. The $3^{\text {rd }}$ sampling site was the activity area of Kiriwong Village. This area is a highlight for visitors to Kiriwong Village where they can enjoy activities by the river (Figure 1). 


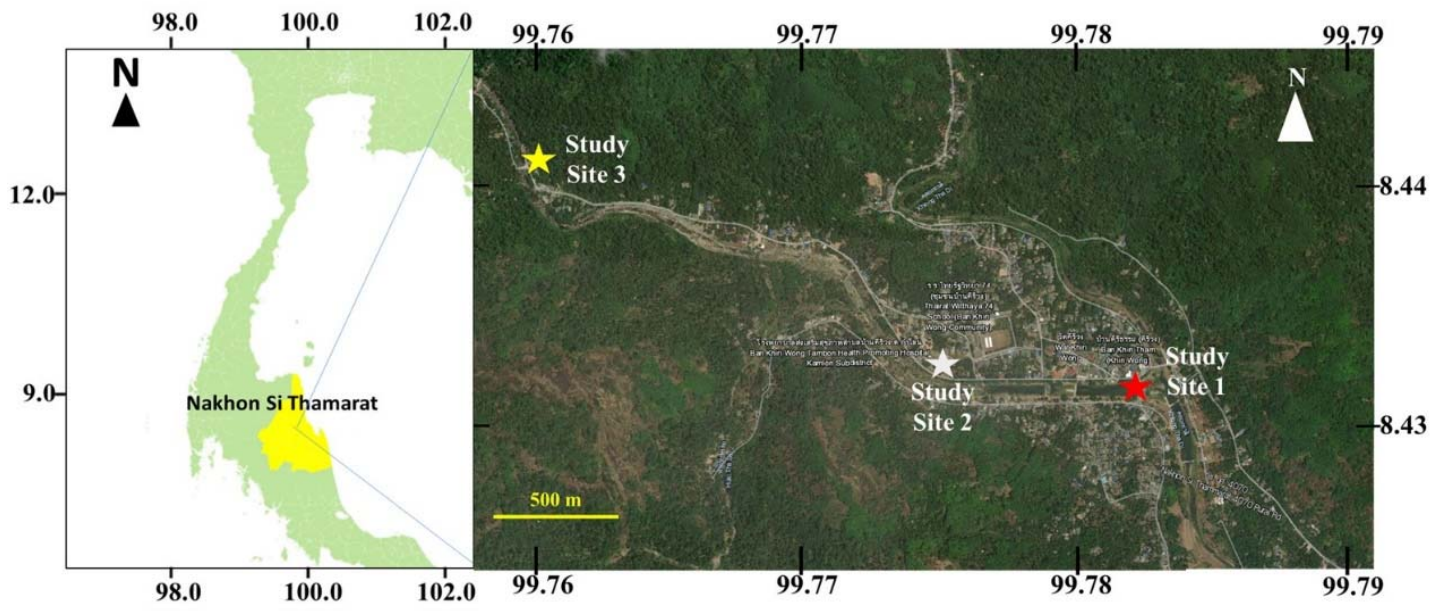

Figure 1 Study area of the three tourist destinations in Kiriwong Village.

(Study site 1: Kiriwong Bridge; Study site 2: Road in the village; study site 3: Activity area).

\section{Nitrogen dioxide sampling}

At Nakhon Si Thammarat, the weather is a major consideration during the rainy season ( 9 months). Kiriwong Village is located in a valley surrounded by forests and experiences rainfall during the summer rainy season. This study also focused on the health risks of $\mathrm{NO}_{2}$ exposure to increase air pollution awareness by the local authorities and residents in the tourist destination area. Thus, sample collection was conducted in the rainy season. $48 \mathrm{NO}_{2}$ samples were collected over a 24-hour period using a passive sampler on weekdays and at weekends during the rainy season in 2 different years (October - November 2018 and July - August 2019).

This study's passive sampler was developed by the Environmental Chemistry Research Laboratory (ECRL), Chiang Mai University, Thailand. Details on device preparation are provided in Bootdee et al. [16]. In brief, the passive sampler consists of 8 passive tubes per set: 5 sample tubes and 3 blank tubes. The absorbent, consisting of filter paper coated with triethanolamine (TEA), was placed at the passive tubes' bottom. Before using, all passive tubes were covered and sealed with parafilm. Covers were removed from the sample tubes during the collection of the $\mathrm{NO}_{2}$ samples, while covers of the blank tubes remained in place. All passive tubes were hung at $1.5-2.0 \mathrm{~m}$ above ground level in a shelter to prevent interference from meteorological conditions. After $24 \mathrm{~h}$, the samples were covered and sealed with parafilm and then transferred to the laboratory for analysis.

The samples were extracted using $2 \mathrm{~mL}$ of deionized water (DI water). The extracted solution $1 \mathrm{~mL}$ was pipetted to mix with $2 \mathrm{~mL}$ of Saltzman reagent to form purple azodye. Finally, the purple solution was measured for absorbance using a spectrophotometer (Dynamica VIS-20, Switzerland) at $540 \mathrm{~nm}$. The $\mathrm{NO}_{2}$ concentration in the sample was calculated from the standard curve of $\mathrm{NO}_{2}^{-}$solution. Details of chemical preparation and extraction are explained in detail in Bootdee et al. [16].

\section{Meteorological conditions}

Meteorological conditions including atmospheric pressure and temperature were measured using a digital barometer, while information of the amount of rain was obtained from the Lan Saka Hydrology Irrigation Center. 


\section{Vehicle counting}

Vehicle numbers were manually counted during the 2-week sampling period. Observation time from 8:00 am to 4:30 pm was subdivided into 27 periods of $18 \mathrm{~min}$. In each period, the number of vehicles was recorded for $3 \mathrm{~min}$, alternating with a break of $15 \mathrm{~min}$. The number of vehicles recorded was then converted to the number for the total observation period.

\section{Statistical analysis}

The t-test was used to compare the concentration of $\mathrm{NO}_{2}$ between weekdays and weekends, while analysis of variance (ANOVA) was applied to compare $\mathrm{NO}_{2}$ concentration among sampling sites. Spearman's correlation was applied for correlation testing between $\mathrm{NO}_{2}$ concentration and meteorological data. Correlation strength was separated by the absolute value of the correlation coefficient and classified as very strong $\left(r_{s}= \pm 0.80\right.$ to \pm 1.0$)$, strong $\left(r_{s}= \pm 0.60\right.$ to \pm 0.79$)$, moderate $\left(r_{s}= \pm 0.40\right.$ to \pm 0.59$)$, weak $\left(r_{s}= \pm 0.20\right.$ to \pm 0.39$)$ and very weak $\left(r_{s}= \pm 0.00\right.$ to \pm 0.19$)$ [17]. Positive and negative correlations were shown by plus and minus symbols, respectively.

\section{Health risk assessment}

Humans are normally exposed to nitrogen dioxide via the inhalation route. Therefore, the noncancer risk from inhalation was considered in this study. The assessment focused on residents of Kiriwong Village who were classified into three age groups as infants ( 0 - 1 year), children ( 1 - 12 years $)$ and adults ( $>12$ years).

The focus of this study was to determine the minimum health risk of $\mathrm{NO}_{2}$ intake. Mean concentration of $\mathrm{NO}_{2}$ measured during the rainy season was applied for health risk evaluation. Concentration of $\mathrm{NO}_{2}$ at weekends was found to be significantly higher than on weekdays. The annual concentration used in the risk assessment was calculated from Eq. (1).

$C_{\text {avg }}=\frac{\left(C_{\text {weekday }} \times N_{\text {weekday }}\right)+\left(C_{\text {weekend }} \times N_{\text {weekend }}\right)}{365}$

where $\mathrm{C}_{\text {avg }}$ is annual concentration of $\mathrm{NO}_{2}\left(\mathrm{mg} \mathrm{m}^{-3}\right), \mathrm{C}_{\text {weekday }}$ and $\mathrm{C}_{\text {weekend }}$ are $\mathrm{NO}_{2}$ concentration on weekdays and weekends, respectively, and $\mathrm{N}_{\text {weekday }}$ and $\mathrm{N}_{\text {weekend }}$ are numbers of weekdays (261 days) and weekend days (104 days) in a year.

The hazard quotient (HQ) was applied to evaluate the health risk from $\mathrm{NO}_{2}$ intake. $\mathrm{HQ}$ is the ratio of potential exposure to pollutants and its adverse effect level. Lina et al. [18], referred to Limy (1996), indicated guidelines for interpreting HQ value as follows: HQ values less than 0.1 shows no hazard exists; HQ values in the range $0.1-1.0$ shows low hazard risk; HQ values in the range 1.1 - 10 shows moderate hazard risk; and finally, HQ values over 10 shows high hazard risk. The HQ value was calculated from Eq. (2) [19].

$H Q=\frac{A D D}{R f D}$

where the average daily dose ADD $\left(\mathrm{mg} \mathrm{kg}^{-1}\right.$ day $\left.^{-1}\right)$ is the exposure of $\mathrm{NO}_{2}$ by respiratory inhalation ( $\mathrm{mg}$ $\mathrm{kg}^{-1}$ day $^{-1}$ ), and the reference dose (RfD) of $\mathrm{NO}_{2}$ is $1.1 \times 10^{-2} \mathrm{mg} \mathrm{kg}^{-1}$ day $^{-1}$ [20].

The ADD of residents was evaluated from Eq. (3) [20,21]. Details of each parameter are presented in Table 1.

$A D D=\frac{C_{a v g} \times I R \times E D \times A F \times E F}{B W \times A T}$

where for ADD of pollutants, $\mathrm{C}_{\text {avg }}$ is the concentration of $\mathrm{NO}_{2}\left(\mathrm{mg} \mathrm{m}^{-3}\right)$ with an assumption that $\mathrm{NO}_{2}$ concentration outdoors $=\mathrm{NO}_{2}$ concentration indoors, $\mathrm{IR}$ is the inhalation rate of residents $\left(\mathrm{m}^{3}\right.$ day $\left.^{-1}\right)$, ED 
http://wjst.wu.ac.th

is the exposure duration (days), AF is the bioavailability factor (unitless), EF is the exposure frequency (day year $\left.{ }^{-1}\right), \mathrm{BW}$ is the body weight of the exposure $(\mathrm{kg})$, and AT is the average time (days).

Table 1 Exposure factor of the residents.

\begin{tabular}{|c|c|c|c|c|c|c|c|}
\hline \multicolumn{2}{|c|}{ Exposed parameters } & Symbol & Unit & $\begin{array}{c}\text { Infant } \\
(0-1 \text { year })\end{array}$ & $\begin{array}{c}\text { Children } \\
\text { (1 - 12 year })\end{array}$ & $\begin{array}{c}\text { Adult } \\
\text { (> 12 year) }\end{array}$ & References \\
\hline \multirow{3}{*}{$\begin{array}{l}\text { Atmospheric } \\
\mathrm{NO}_{2}\end{array}$} & Site 1 & $\mathrm{C}_{\mathrm{avg}}$ & $\mathrm{mg} \mathrm{m}^{-3}$ & 0.057 & 0.057 & 0.057 & This study \\
\hline & Site 2 & $\mathrm{C}_{\mathrm{avg}}$ & $\mathrm{mg} \mathrm{m}^{-3}$ & 0.030 & 0.030 & 0.030 & This study \\
\hline & Site 3 & $\mathrm{C}_{\text {avg }}$ & $\mathrm{mg} \mathrm{m}^{-3}$ & 0.032 & 0.032 & 0.032 & This study \\
\hline \multicolumn{2}{|c|}{ Body weight } & $\mathrm{BW}$ & $\mathrm{kg}$ & 10 & 26 & 55 & {$[22,23]$} \\
\hline \multicolumn{2}{|c|}{ The average time } & AT & day & \multicolumn{3}{|c|}{$\mathrm{ED} \times 365$ (day/year) } & {$[22]$} \\
\hline \multicolumn{2}{|c|}{ The exposure duration } & ED & year & 1 & 6 & 30 & \\
\hline \multicolumn{2}{|c|}{ Bioavailability factor } & $\mathrm{AF}$ & - & 1 & 1 & 1 & {$[22]$} \\
\hline \multicolumn{2}{|c|}{ The exposure frequency } & $\mathrm{EF}$ & day year-1 & 365 & 365 & 365 & \\
\hline \multicolumn{2}{|c|}{ Inhalation rate } & IR & $m^{3}$ day $^{-1}$ & 4.5 & 10 & 20 & {$[22]$} \\
\hline
\end{tabular}

\section{Risk area assessment using air mass movements}

This study used air mass movements to conduct a preliminary evaluation of the risk area from $\mathrm{NO}_{2}$ exposure. A forward trajectory is the path of an air mass moving forward from its origin. The forward trajectory analysis helps determine the dispersion of pollutants and is usually calculated by the Hybrid Single-Particle Lagrangian Integrated Trajectory (HYSPLIT) model. The HYSPLIT model is widely used to compute long-range transport of various air pollutants, including $\mathrm{PM}_{10}, \mathrm{NO}_{2}$, and $\mathrm{O}_{3}[24,25]$, because this model is simple, utilizes quick responses, and is complete for computing [26]. Forward trajectory analysis of $\mathrm{NO}_{2}$ during the study period was calculated using HYSPLIT's TrajStat Trajectory Statistics function, which was processed by the HYSPLIT model [27]. The trajectory model's meteorological input was the Global Data Assimilation System (GDAS) and meteorological data $\left(1^{\circ} \times 1^{\circ}\right)$. Since the lifespan of atmospheric $\mathrm{NO}_{2}$ is about $4 \mathrm{~h}$ [28], a 2-hour forward trajectory was calculated in this study with the assumption of non-degradation of the pollutant during air mass movement. Moreover, the trajectories were calculated twice per day at traffic congestion periods (10:00 and 15:00 Local Sidereal Time (LST)) at $10 \mathrm{~m}$ above ground level (AGL) because these were times of maximal tourist arrivals and departures. A total of 1,460 trajectories (January 2018 - December 2019) per sampling site were clustered using the TrajStat application.

The forward trajectory (path of air movement) represented the direction of receptor exposure to the pollutant, while the number of trajectories indicated the annual frequency that the receptor was exposed to the pollutant. The exposure frequency (EF) of each cluster was calculated by Eq. (4). After that, the EF value was then calculated for the HQ value for each of the clustered trajectories in order to indicate the risk area of $\mathrm{NO}_{2}$ exposure.

$E F_{i}=\%$ Cluster $_{i} \times E F$

where $\mathrm{EF}_{\mathrm{i}}$ is the exposure frequency of cluster $\mathrm{i}$, and $\%$ cluster $_{\mathrm{i}}$ is the percentage of trajectories in cluster $\mathrm{i}$. 
http://wjst.wu.ac.th

\section{Results and discussion}

\section{Nitrogen dioxide concentration}

The concentration of nitrogen dioxide collected from Kiriwong Village during the rainy season ranged from 21.6 to $111.9 \mathrm{\mu g} \mathrm{m}^{-3}$. Air samples in this study were collected over $24 \mathrm{~h}$, while Thailand's air quality standard was regulated for $1 \mathrm{~h}$ and the annual mean of $\mathrm{NO}_{2}$ concentration. Therefore, $\mathrm{NO}_{2}$ concentrations in this study were compared with Japan's ambient air quality standard of $\mathrm{NO}_{2}$ for $24 \mathrm{~h}$. Results showed that $\mathrm{NO}_{2}$ concentrations were acceptable under the Japanese standard of $113 \mu \mathrm{g} \mathrm{m}^{-3}$. Mean concentration of $\mathrm{NO}_{2}$ was highest at study site $1\left(98.6\right.$ and $40.1 \mu \mathrm{g} \mathrm{m}^{-3}$ ) for weekends and weekdays, respectively, and significantly different from the other 2 sites $(\mathrm{p}<0.05)$. No significant difference in concentration was observed between study site 2 and study site 3 (Figure 2). However, $\mathrm{NO}_{2}$ concentrations strongly correlated among the 3 study sites with coefficients ranging from 0.6 to 0.88 at 99 $\%$ confidence level (Spearman's correlation test) because all the site locations were on the same road. Study site 1 was located at the T-intersection and tourists usually pass this site before going to study sites 2 and 3. Observations of traffic volumes at all sites showed that the volume at site 1 was about twice that at sites 2 and 3. Moreover, site 1, known as the gate of Kiriwong Village, is renowned as one of the landmarks of Kiriwong Village. Tourists always stop for a while at this site for photos without turning off their engines; thus, enormous quantities of pollutants accumulate in this area. Areas with traffic delay ( slow vehicle flow), had higher $\mathrm{NO}_{2}$ concentration than areas with free-flow traffic $[3,4]$. Thus, traffic delay increased the impact of pollutant emission and accumulation in the area.

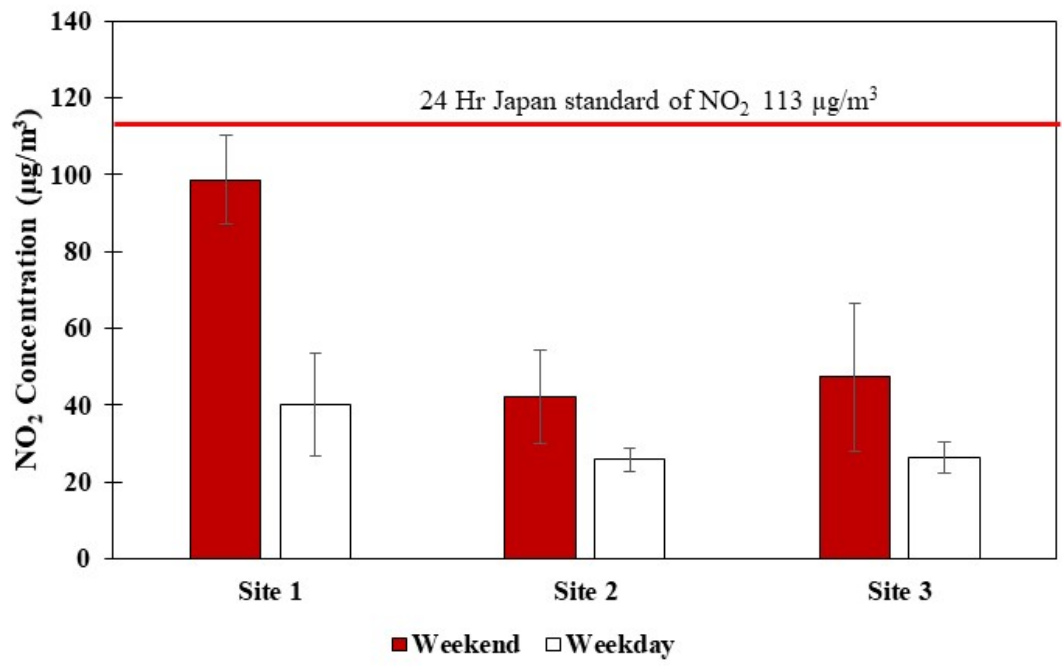

Figure 2 Comparison of nitrogen dioxide concentration between weekdays and weekends at Kiriwong Village during the rainy season

Nitrogen dioxide concentrations on weekdays ranged between 26.7 - 53.5, 22.7 - 28.9 and 22.1 $30.5 \mu \mathrm{g} \mathrm{m}^{-3}$ for study sites 1,2 and 3, respectively. Concentrations on weekdays and at weekends were significantly different $(\mathrm{p}<0.05)$ at $95 \%$ confidence level. Concentrations at weekends ranged between $87.0-110.2,30.0-54.5$ and $27.9-66.6 \mu \mathrm{g} \mathrm{m}^{-3}$ for study sites 1,2 and 3 , respectively. These were 1.6 to 2.5 times greater than weekday values. This result was related to the number of vehicles at weekends ( 4,000 - 9,000 vehicles) as 1.5 to 2 times the number on weekdays ( 3,000-4,500 vehicles) because tourists often make longer trips at weekends than on weekdays. The most common form of vehicular transport found in Kiriwong Village (55\%) was a motorcycle, but large numbers of cars (45\%) were also recorded. Moreover, tourists used cars at weekends twice as much as during weekday trips. Therefore, 
http://wjst.wu.ac.th

high traffic density occurred on local streets resulting in delays or traffic congestion [29-31]. The level of air pollutants in tourist destinations differs from megacities such as Moscow, Tokyo and Osaka, where $\mathrm{NO}_{2}$ is largely emitted on weekdays rather than at weekends because of the operation of industrial enterprises and traffic intensity [32,33]. The $\mathrm{NO}_{2}$ concentration in each area related to the travel behavior of tourists and the system of transportation.

There was no significance between $\mathrm{NO}_{2}$ concentration and meteorological conditions of temperature, air pressure, and rainfall. However, pollution levels showed a weak positive relationship with air pressure $\left(r_{s}\right.$ value $=0.16$ to 0.26$)$, while a very weak negative relationship was evident between temperature $\left(r_{s}\right.$ value $=-0.19$ to -0.010$)$ and rainfall amount $\left(r_{s}\right.$ value $=-0.18$ to -0.02$)$. This result indicated that high pressure was more likely caused by nitrogen dioxide accumulation in the area [34]. The study area was located in a valley, and temperature inversion in which a layer of cool air at the surface was overlain by a layer of warmer air occurred, especially in the early morning and evening. This inversion led to accumulation of air pollutants in the area. Longer sunshine duration and higher air temperature reduced temperature inversion formation, which was more conducive to $\mathrm{NO}_{2}$ diffusion [35]. Rainfall is affected by the concentration of air pollutants in terms of the atmospheric washing effect, and lower $\mathrm{NO}_{2}$ levels are always observed after a rainy day. Results here concurred with many other studies, where variations in $\mathrm{NO}_{2}$ concentration in areas located near emission sources were influenced by local anthropogenic sources such as traffic volume and traffic flow, rather than local meteorological conditions $[16,36,37]$.

\section{Health risk assessment of nitrogen dioxide exposure}

The hazard quotient (HQ) was applied to estimate non-carcinogenic risks to humans from $\mathrm{NO}_{2}$ intake by inhalation. The annual concentration of each study site was calculated following Eq. (1), with concentrations of $56.8,30.5$ and $32.3 \mu \mathrm{g} \mathrm{m} \mathrm{m}^{-3}$ for study sites 1,2 and 3 , respectively. Annual concentrations were then calculated for the HQ value using Eqs. (2) and (3), with the assumption that the outdoor and indoor concentrations of $\mathrm{NO}_{2}$ were equal because of the open house style. The HQ value of this village ranged from 1.0 to 2.3 (Figure 3), indicating unacceptable exposure conditions with noncancer risks for human health. The highest HQ value was found at study site $1(1.9-2.3)$, followed by study site $3(1.1-1.3)$. Both these sites presented moderate hazard levels for all resident groups [18], while the hazard level was low for adult residents at study site 2 [18]. The HQ value contrasted with $\mathrm{NO}_{2}$ concentration, which was within the accepted ambient air quality standard. These results indicated that local residents were safe from acute effects, but they were at risk of long-term health effects from exposure to $\mathrm{NO}_{2}$.

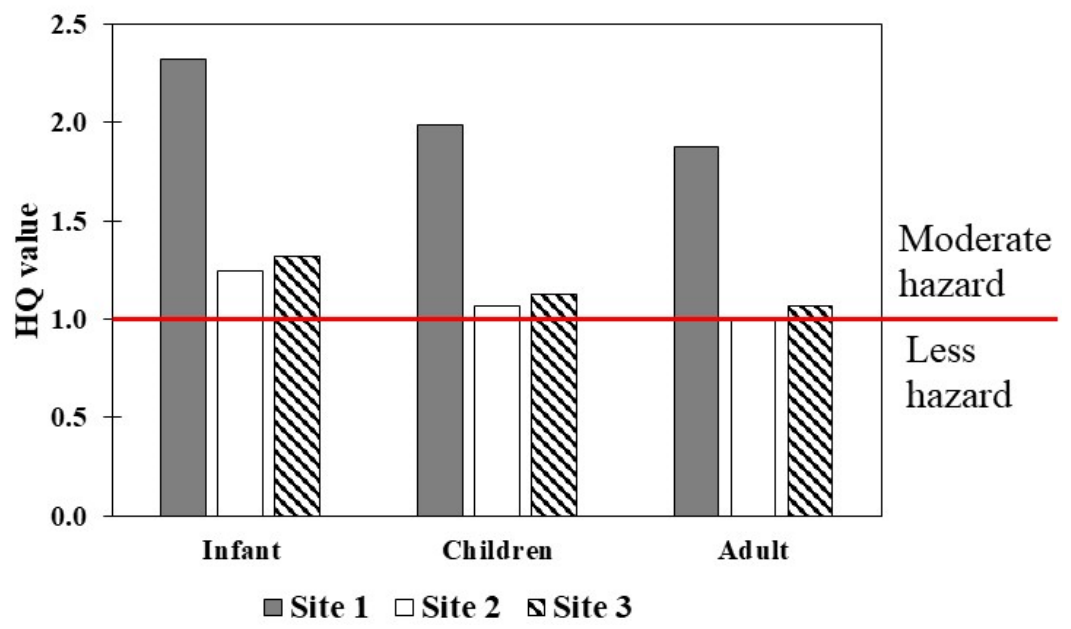

Figure 3 HQ value comparison among the resident groups 
http://wjst.wu.ac.th

The highest risk group of residents was determined as the infant group $(1.3-2.3)$, followed by children $(1.1-2.0)$, and then adults $(1.0-1.9)$. This was most likely due to the highest $\mathrm{NO}_{2}$ intake per unit body weight for infants. This result concurred with a study by Bootdee et al. [38] that determined the HQ value of children exposed to $\mathrm{NO}_{2}$ at primary schools in Rayong City as higher than that of adults. Other atmospheric pollutants indicated that the HQ of children $(<8$ years old $)$ from formaldehyde exposure in facilities in South Korea was higher than the acceptable level of 1, while adults were below the acceptable level [39]. Similarly, the risk to child residents ( $<8$ years old) was $12 \%$ greater than the risk to adolescents (12 - 14 years) exposed to $\mathrm{PM}_{10}$ in the Brazilian Amazon region [40]. The total risk (HI) of non-carcinogenic pollutants for adult residents was half that of children and infants from exposure to $\mathrm{PM}_{10}$ and $\mathrm{NO}_{2}$ in Kraków, Poland. Moreover, this study showed that the HI of women (3.19) was higher than that of men (2.67) because of the lower body weight of women [19]. However, HQ value was also based on the activity patterns of the receptor. Women spend more time in dwellings, and the HQ values of indoor VOCs for women were higher than those for men [41]. Du et al. [42] indicated that working males had higher risk levels from hazardous air pollutant (HAP) exposure than females due to their greater inhalation rate and longer working hours than females. Therefore, changing personal behavior to reduce air pollution exposure, such as spending more time in airtight buildings and avoiding outdoor activities during air pollution episodes (weekends), was suggested to reduce the residents' human health risks [43]. Traffic management and limitations on vehicle numbers at tourist destinations should also be considered to reduce pollutant concentrations at the source.

\section{Risk area evaluation from nitrogen dioxide exposure}

Risk area evaluation in this study was based on air mass movement because $\mathrm{NO}_{2}$ is normally distributed to the downwind area via movement of air. Higher clustered trajectories indicated higher exposure frequency and health risk from exposure to pollutants. The trajectories of all study areas were similar because of the short distance between the sites. Therefore, the risk area was focused at study site 1 because this had the highest HQ value.

A total of 1,460 forward trajectories were clustered into two groups (Figure 4), which consisted of cluster 1 (yellow line): 861 trajectories (59\%) and cluster 2 (blue dotted line): 599 trajectories (41\%). Air mass trajectories in cluster 1 were influenced by the northeast monsoon from October to February $(5$ months), while the southwest monsoon during May to September ( 5 months) was mainly impacted by Cluster 2 [44]. Trajectories in cluster 1 were also affected by the sea breeze to the east during the monsoon transition month. The number of trajectories in cluster 1 was greater than those in Cluster 2.

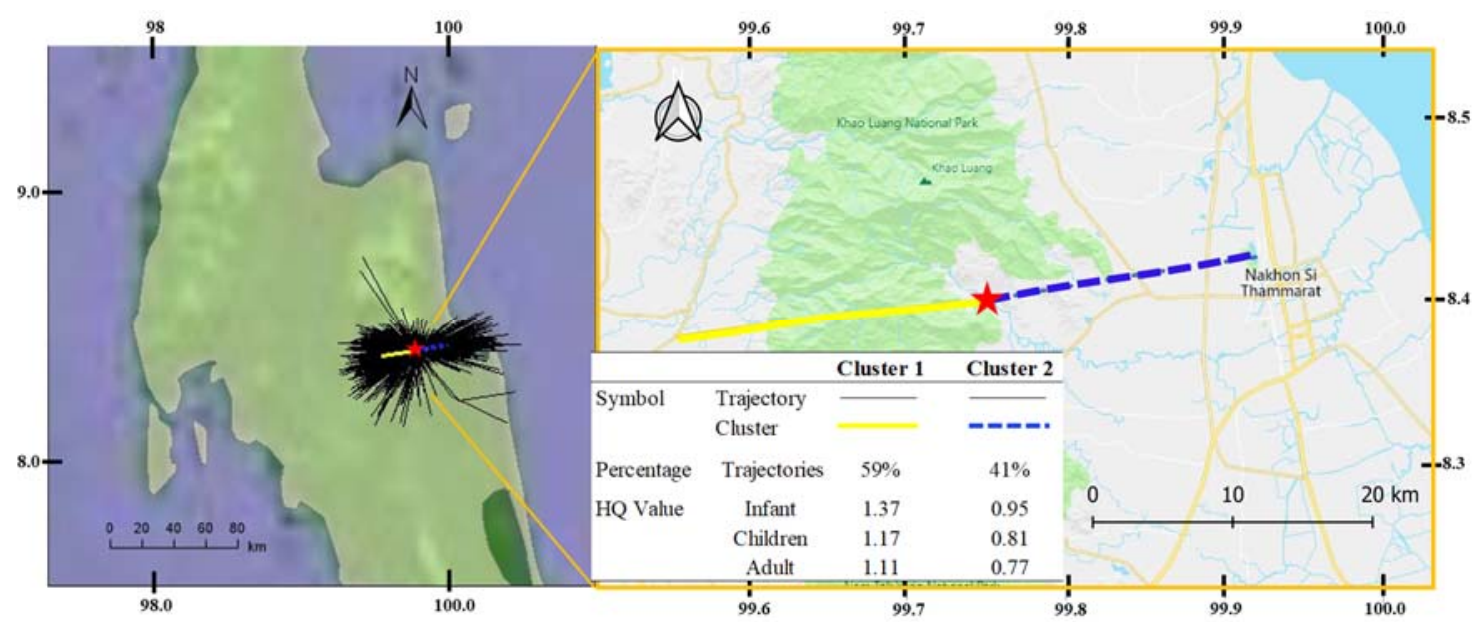

Figure 4 HQ values of cluster trajectories. 
http://wjst.wu.ac.th

The number of trajectories in each cluster was converted to the exposure frequency (EF), and the EF of each cluster was then used to calculate the HQ value following Eqs. (3) and (4), respectively. The HQ value in each cluster implied that air mass movement analysis was clearly indicated risk area for longterm health effects from exposure to air pollutants, as presented in Table 2.

Table 2 Exposure frequency (EF) and HQ value of each cluster.

\begin{tabular}{cccccc}
\hline \multirow{2}{*}{$\begin{array}{c}\text { Study } \\
\text { area }\end{array}$} & Cluster & $\begin{array}{c}\text { The exposure } \\
\text { frequency; } \mathbf{E F} \\
\left.\text { (Day year }^{-1}\right)\end{array}$ & $\begin{array}{c}\text { Infant } \\
(\mathbf{0}-\mathbf{1} \text { year })\end{array}$ & $\begin{array}{c}\text { Children } \\
(\mathbf{1}-\mathbf{1 2} \text { year })\end{array}$ & $\begin{array}{c}\text { Adult } \\
(>\mathbf{1 2} \text { year })\end{array}$ \\
\hline Site 1 & Cluster 1 & 215 & 1.37 & 1.17 & 1.11 \\
& Cluster 2 & 150 & 0.95 & 0.81 & 0.77 \\
Site 2 & Cluster 1 & 215 & 0.74 & 0.63 & 0.59 \\
& Cluster 2 & 150 & 0.51 & 0.44 & 0.41 \\
Site 3 & Cluster 1 & 215 & 0.78 & 0.67 & 0.63 \\
& Cluster 2 & 150 & 0.54 & 0.46 & 0.44 \\
\hline
\end{tabular}

The exposure frequency of cluster 1 was 215 days, while cluster 2 was 150 days. The HQ values of cluster 1 study site 1 for all resident groups were higher than 1 . The area to the west of study site 1 showed the highest risk, where the hazard from $\mathrm{NO}_{2}$ exposure was unacceptable for residents. Therefore, residents should avoid outdoor activities at weekends and spend more time in houses with windows shut tightly [43], whereas cluster 2 hazard was acceptable. HQ values for study sites 2 and 3 indicated minimal hazard from inhalation intake of $\mathrm{NO}_{2}$. Results implied that the tourism authority should immediately take steps to improve traffic management in tourism areas by extending public transport and limiting tourist or vehicle numbers to reduce annual $\mathrm{NO}_{2}$ concentration to less than $0.25 \mu \mathrm{g} \mathrm{m}^{-3}$ and to maintain the HQ value at an acceptable level.

\section{Conclusions}

Nitrogen dioxide levels emitted by traffic in the tourism destination of Kiriwong Village were assessed using passive sampling. The $\mathrm{NO}_{2}$ concentration was highest at landmark areas with high traffic density. Pollutant concentration at weekends was 2 - 3 times greater than on weekdays and positively correlated with the number of tourists visiting the area. However, $\mathrm{NO}_{2}$ concentrations were within the 24hour Japan air quality standard $\left(113 \mu \mathrm{g} \mathrm{m}^{-3}\right)$. Anthropogenic sources such as traffic volume and traffic flow mainly influenced pollutant levels. A toxicity assessment determined that $\mathrm{NO}_{2}$ exposure might cause long-term adverse health effects among residents, especially those living to the west of study site 1 . Sensitive residents should avoid outdoor activities during periods of peak traffic volume. Moreover, the tourism authority should be aware of the environmental degradation resulting from tourist activities and transportation systems in tourist destinations. Tourism management should be improved as the $1^{\text {st }}$ priority by controlling visitor numbers and providing adequate public transportation systems and parking areas.

\section{Acknowledgements}

The authors offer sincere thanks to Ms. Nuttida Nuttee and Ms. Narisa Ratthong for their kind assistance in sample collection. The support from the School of Languages and General Education is also greatly appreciated. 
http://wjst.wu.ac.th

\section{References}

[1] NL Gilbert, MS Goldberg, JR Brook and M Jerrett. The influence of highway traffic on ambient nitrogen dioxide concentrations beyond the immediate vicinity of highways. Atmos. Environ. 2007; 41, 2670-3.

[2] PG Obara, CL Roberts, CH Young and CD Williams. Validating the correlation of traffic-associated hydrocarbon and nitrogen dioxide with distance from a trunk road within a rural environment in UK. Microchem. J. 2011; 99, 138-44.

[3] S Mukerjee, L Smith, H Brantley, C Stallings, L Neas, S Kimbrough and R Williams. Comparison of modeled traffic exposure zones using on-road air pollution measurements. Atmos. Pollut. Res. $2015 ; 6,82-7$.

[4] L Smith, S Mukerjee, K Kovalcik, E Sams, C Stallings, E Hudgens, J Scott, T Krantz and L Neas. Near-road measurements for nitrogen dioxide and its association with traffic exposure zones. Atmos. Pollut. Res. 2015; 6, 1082-6.

[5] B Beckerman, M Jerrett, JR Brook, DK Verma, MA Arain and MM Finkelstein. Correlation of nitrogen dioxide with other traffic pollutants near a major expressway. Atmos. Environ. 2008; 42, 275-90.

[6] CJ Chang and HH Yang. Impact on eye health regarding gaseous and particulate pollutants. Aerosol. Air Qual. Res. 2020; 20, 1695-9.

[7] G Favarato, HR Anderson, R Atkinson, G Fuller, I Mills and H Walton. Traffic-related pollution and asthma prevalence in children. Quantification of associations with nitrogen dioxide. Air Qual. Atmos. Health. 2014; 7, 459-66.

[8] Y Jiang, Y Niu, Y Xia, C Liu, Z Lin, W Wang, Y Ge, X Leia, C Wang, J Caia, R Chena and H Kan. Effects of personal nitrogen dioxide exposure on airway inflammation and lung function. Environ. Res. 2019; 177, 108620 .

[9] J Song, Y Liu, M Lu, Z An, J Lu, L Chao, L Zheng, J Li, S Yao, W Wu and D Xu. Short-term exposure to nitrogen dioxide pollution and the risk of eye and adnexa diseases in Xinxiang, China. Atmos. Environ. 2019; 218, 117001.

[10] Y Duan, Y Liao, H Li, S Yan, Z Zhao, S Yu, Y Fu, Z Wang, P Yin, J Cheng and H Jiang. Effect of changes in season and temperature on cardiovascular mortality associated with nitrogen dioxide air pollution in Shenzhen, China. Sci. Total Environ. 2019; 697, 134051.

[11] Tourism Statistic 2019, Available at: https://www.mots.go.th/old/more_news.php?cid=411, accessed May 2020.

[12] O Saenz-de-Miera and J Rosselló. The responsibility of tourism in traffic congestion and hypercongestion: A case study from Mallorca, Spain. Tour. Manag. 2012; 33, 466-79.

[13] O Saenz-de-Miera and J Rosselló. Modeling tourism impacts on air pollution: The case study of $\mathrm{PM}_{10}$ in Mallorca. Tour. Manag. 2014; 40, 273-81.

[14] $\mathrm{H}$ Bae, W Yang and M Chung. Indoor and outdoor concentrations of RSP, $\mathrm{NO}_{2}$ and selected volatile organic compounds at 32 shoe stalls located near busy roadways in Seoul, Korea. Sci. Total Environ. 2004; 323, 99-105.

[15] R Janta, J Kaewrat, C Rattikansukha and S Sichum. Measurement of nitrogen dioxide concentration in traffic areas of Nakhon Si Thammarat Province and health risk assessment (in Thai). J. King Mongkut's University of Technology North Bangkok 2020; 30, 481-94.

[16] S Bootdee, P Chalemrom and S Chantara. Validation and field application of tailor-made nitrogen dioxide passive samplers. Int. J. Environ. Sci. Technol. 2012; 9, 515-26.

[17] A Rauf, H Li, S Ullah, L Meng, B Wang and M Wang. Statistical study about the influence of particle precipitation on mesosphere summer echoes in polar latitudes during July 2013. Earth Planets Space 2018; 70, 1-13.

[18] ND Lina, JC Engelbrecht, CY Wright and MA Osthuizen. Human health risks posed by exposure to $\mathrm{PM}_{10}$ for four life stages in a low socio: Economic community in South Africa. Pan Afr. Med. J. $2014 ; 18,1-12$ 
http://wjst.wu.ac.th

[19] US EPA. Concepts methods and data sources for cumulative health risk assessment of multiple chemicals, exposures and effects: A resource document, EPA/600/R-06/013F. In: Proceedings of the National Center for Environmental Assessment, Office of Research and Development, Cincinnati, United States, 2007.

[20] V Garbero, A Montaldo, N Lazovic, P Salizzoni, S Berrone and L Soulhac. The impact of the urban air pollution on the human health: A case-study in Turin. Air Pollut. Model. App. 2011; 11, 729-32.

[21] ATSDR. Public health assessment guidance manual. Agency for Toxic Substances and Disease Registry, 2005.

[22] A Gruszecka-Kosowska. Assessment of the Krakow inhabitants' health risk caused by the exposure to inhalation of outdoor air contaminants. Stoch. Environ. Res. Risk Assess. 2018; 32, 485-99.

[23] R Onchang and P Hemwat. Students' perception of industrial environmental stimuli: Focus on particulate matter (in Thai). Sci. Tech. 2016; 3, 349-62.

[24] K Vellingiri, KH Kim, JM Lim, JH Lee, CJ Ma, BH Jeon, JR Sohn, P Kumar and CH Kang. Identification of nitrogen dioxide and ozone source regions for an urban area in Korea using back trajectory analysis. Atmos. Res. 2016; 176-177, 212-21.

[25] P Punsompong and S Chantara. Identification of potential sources of $\mathrm{PM}_{10}$ pollution from biomass burning in northern Thailand using statistical analysis of trajectories. Atmos. Pollut. Res. 2018; 9, 1038-51.

[26] T Rungratanaubon, S Bualert, P Choomanee and B Shutes. Vertical variation of nitrogen oxide (NOx) concentration using a backward air mass trajectories model in an urban area of Bangkok, Thailand. KMUTNB Int. J. Appl. Sci. Technol. 2018; 11, 73-81.

[27] YQ Wang, XY Zhang and RR Draxler. "TrajStat: GIS-based software that uses various trajectory statistical analysis methods to identify potential sources from long-term air pollution measurement data. Environ. Model. Softw. 2009; 24, 938-9.

[28] S Beirle, KF Boersma, U Platt, MG Lawrence and T Wagner. Megacity emissions and lifetimes of nitrogen oxides probed from space. Science 2011; 333, 1737-9.

[29] S Anowar, S Yasmin and R Tay. Comparison of crashes during public holidays and regular weekends. Accid. Anal. Prev. 2013; 51, 93-7.

[30] M Cools, E Moons and G Wets. Assessing the impact of public holidays on travel time expenditure. Transp. Res. Rec. 2010; 2157, 29-37.

[31] L Yang, Q Shen and Z Li. Comparing travel mode and trip chain choices between holidays and weekdays. Transp. Res. Part A Policy Pract. 2016; 91, 273-85.

[32] NF Elansky, AV Shilkin, NA Ponomarev, EG Semutnikova and PV Zakharova. Weekly patterns and weekend effects of air pollution in the Moscow megacity. Atmos. Environ. 2015; 224, 117303.

[33] Y Sadanaga, S Shibata, M Hamana, N Takenaka and H Bandow. Weekday/weekend difference of ozone and its precursors in urban areas of Japan, focusing on nitrogen oxides and hydrocarbons. Atmos. Environ. 2008; 42, 4708-23.

[34] L Wang, J Wang, X Tan and C Fang. Analysis of NOx pollution characteristics in the atmospheric environment in Changchun City. Atmosphere 2020; 11, 2-12.

[35] Y Zhang. Dynamic effect analysis of meteorological conditions on air pollution: A case study from Beijing. Sci. Total Environ. 2019; 684, 178-85.

[36] S Pintarić, T Bodrozić-Dzakić, H Pintarić, Z Rusan and S Ljubicić. Effects of nitrogen dioxide and meteorological conditions on the number of patients presenting to emergency department. Acta. Clin. Croat. 2012; 51, 9-15.

[37] D Roberts-Semple, F Song and Y Gao. Seasonal characteristics of ambient nitrogen oxides and ground-level ozone in metropolitan northeastern New Jersey. Atmos. Pollut. Res. 2012; 3, 247-57.

[38] S Bootdee, S Phantu, P Lamlongrat and T Khumphai. Indoor nitrogen dioxide investigation and health risk assessment in primary schools at Rayong City, Thailand. Curr. J. Appl. Sci. Technol. 2020; 19, 248-62.

[39] SH Hwang, J Roh and WM Park. Evaluation of $\mathrm{PM}_{10}, \mathrm{CO}_{2}$, airborne bacteria, TVOCs and formaldehyde in facilities for susceptible populations in South Korea. Environ. Pollut. 2018; 242, 700-8. 
http://wjst.wu.ac.th

[40] BFAD Oliveira, E Igotti, P Artzxo, PHN Saldiva, WL Juger and S Hacon. Risk assessment of PM 2.5 to child residents in Brazilian Amazon region with biofuel production. Environ. Health 2012; 11, 64.

[41] Z Cheng, B Li, W Yu, H Wang, T Zhang, J Xiong and Z Bu. Risk assessment of inhalation exposure to VOCs in dwellings in Chongqing, China. Toxicol. Res. 2018; 7, 59-72.

[42] Z Du, J Mo and Y Zhang. Risk assessment of population inhalation exposure to volatile organic compounds and carbonyls in urban China. Environ. Int. 2014; 73, 33-45.

[43] R Laumbach, Q Meng and H Kipen. What can individuals do to reduce personal health risks from air pollution? J. Thorac. Dis. 2015; 7, 96-107.

[44] The Climate of Nakhon Si Thammarat, Thailand, Available at: http://www.marine.tmd.go.th/thai/ tus_type, accessed May 2020. 